\title{
PERENCANAAN SISTEM AZIMUTH LENGANRCWS (REMOTE CONTROL WEAPON SYSTEM)PADA ROBOT TEMPUR KOTA
}

\author{
Aris Munandar ${ }^{1}$, Jumiadi $^{2 *}$, Gunarko $^{1}$ \\ ${ }^{1}$ Jurusan Teknik Otoranpur, Poltekad Malang \\ ${ }^{2}$ Jurusan Teknik Mesin, Fakultas Teknik, Universitas Merdeka Malang \\ *Email corresponding author:
}

\begin{abstract}
Abstrak
Robot tempur kotamerupakan salah satu alat yang akan dirancang oleh mahasiswa dari Poltekad Kodiklat TNI AD untuk membantu pertempuran di medan perkotaan dengan kontrol jarak jauh serta pergerakan khusus dari roda mecanum wheel. efektifitas waktu dan fleksibilitas gerakan dalam menentukan target atau musuh pada setiap sudut dengan cepat adalah salah satu syarat penting dalam pertempuran perkotaan untuk mengurangi kerugian personil maupun materil. Perencanaan system azimuth RCWS adalah satu cara untuk memenuhi aspek penting pada pertempuran perkotaan tersebut. Kelebihan dari sistem azimuth lengan RCWS ini adalah pada desain sistem azimuth, sistem azimuth ini menggunakan prinsip seperti motor stater pada mobil yaitu menggunakan slipring brush bertujuan agar pada saat lengan berputar kabel atau sistem kelistrikan pada robot tidak terlilit pada poros azimuth dan aliran listrik dari baterai akan mengalir melalui slipring brush. Kelebihan lain dari sistem azimuth ini adalah gerakan yang lebih smooth dan kecepatan berputar $360^{\circ}$ dengan waktu kurang dari 8 detik.Dalam perencanaan system Azimuth diperoleh hasil dengan beban maksimal $16,594 \mathrm{~kg}$, dengan kecepatan putar azimuth $0,117 \mathrm{~m} / \mathrm{s}$, diameter roda gigi pinion $27 \mathrm{~mm}$, diameter roda gigi besar $303 \mathrm{~mm}$ dan gaya tangensial pada gigi pinion 61,35 kg sedangkan gigi besar 5,467 $\mathrm{kg}$. Pada poros tegangan geser yang terjadi sebesar $0,379 \mathrm{~kg}<$ tegangan geser ijin sebesar $4,33 \mathrm{~kg}$. Pada pasak tegangan geser $0,478 \mathrm{~kg}<$ tegangan geser ijin sebesar 4,3 kg. denganmenggunakan bantalan no 6006 dan pelumasan menggunakan pelumasan gemuk.
\end{abstract}

Kata Kunci: Mecanum wheel, RCWS (Remote Control Weapon System)dan system Azimuth.

\begin{abstract}
The city combat robot is one of the tools that will be designed by students from the Army Military Command Polytechnic to help combat on urban terrain with remote control and special movement of the Mecanum wheel. the effectiveness of time and the flexibility of movement in determining targets or enemies at any angle quickly is one of the important conditions in urban battles to reduce personnel and material losses. RCWS azimuth system planning is one way to fulfill important aspects of the urban battle. The advantages of the RCWS arm azimuth system are the azimuth system design, the azimuth system uses principles such as motor stater in a car that uses a slipring brush so that when the arm rotates the cable or the electrical system on the robot is not wrapped around the azimuth shaft and the electric current from the battery will flow through the slipring brush. Another advantage of this azimuth system is smoother movement and 3600 rotational speed in less than 8 seconds. In the Azimuth system planning, the results obtained with a maximum load of $16.594 \mathrm{~kg}$, with azimuth rotational speed of $0.117 \mathrm{~m} / \mathrm{s}$, pinion gear diameter of $27 \mathrm{~mm}$, diameter of large gear $303 \mathrm{~mm}$ and tangential force on pinion gear of $61.35 \mathrm{~kg}$ while large teeth of $5.467 \mathrm{~kg}$. On the shaft shear stress that occurs at $0.379 \mathrm{~kg}<$ permit shear stress of $4.33 \mathrm{~kg}$. At the stake shear stress $0.478 \mathrm{~kg}<$ permit shear stress of $4.3 \mathrm{~kg}$. by using bearing no 6006 and lubrication using grease lubrication.
\end{abstract}

Keywords :Mecanum wheel, RCWS (Remote Control Weapon System) dan system Azimuth.

\section{PENDAHULUAN}

Robot tempur kota merupakan salah satu alat yang akan dirancang oleh mahasiswa dari Poltekad Kodiklat TNI AD untuk membantu pertempuran di medan perkotaan dengan kontrol jarak jauh serta pergerakan khusus dari roda mecanum wheel. Salah satu hal penting pada pertempuran perkotaan untuk mengurangi kerugian personil maupun materil adalah efektifitas waktu dan fleksibilitas gerakan dalam menentukan target atau musuh pada setiap sudut dengan cepat.

Berdasarkan fakta di atas, perlu adanya penambahan gerakan azimuth lengan RCWS pada robot tempur kota ini untuk lebih meningkatkan daya tempur dan daya gerak 
dalam pertempuran di perkotaan. Gerakan azimuth itu sendiri adalah gerakan berputar $360^{\circ}$ ke kiri ataupun ke kanan dengan berpusat pada suatu titik. Penambahan gerakan azimuth lengan RCWS pada robot tempur kota ini berfungsi untuk menambah efektifitas waktu atau menambah kecepatan dalam menentukan target atau musuh pada setiap sudut dan gerakan robot ini menjadi praktis karena tanpa harus memutar robot lengan RCWS sudah bisa berputar hingga $360^{\circ}$ dengan waktu yang lebih cepat.

Kelebihan dari sistem azimuth lengan RCWS ini adalah pada desain sistem azimuth, sistem azimuth ini menggunakan prinsip seperti motor stater pada mobil yaitu menggunakan slipring brush bertujuan agar pada saat lengan berputar kabel atau sistem kelistrikan pada robot tidak terlilit pada poros azimuth dan aliran listrik dari baterai akan mengalir melalui slipring brush. Kelebihan lain dari sistem azimuth ini adalah gerakan yang lebih smooth dan kecepatan berputar $360^{\circ}$ dengan waktu kurang dari 8 detik.

Sehingga berdasarkan permasalahan dan penjelasan di atas penulis akan mengaplikasikanya dalam bentuk skripsi dengan judul "PERENCANAAN SISTEM AZIMUTH PADA LENGAN RCWS (REMOTE CONTROL WEAPON SYSTEM) PADA ROBOT TEMPUR KOTA" sehingga dengan adanya penambahan gerakan azimuth pada lengan RCWS robot tempur kota ini, diharapkan dapat menambah daya tempur atau daya gerak dari robot tempur kota menjadi lebih cepat dalam mengunci target.

\section{Tujuan Penelitian}

1. Memberi masukan kepada pimpinan TNI AD dalam usaha mewujudkan kemandirian teknologi dan memoderenisasi di bidang alutsista.

2. Mendapatkan desain sistem azimuth pada lengan RCWS robot tempur kota dengan gerakan yang lebih smooth.

\section{Rumusan Masalah}

1 Bagaimana perencanaan roda gigi, poros, pasak, bantalan pada sistem azimuth?

2 Bagaimana menentukan bahan dan tipe komponen system azimuth sesuai kebutuhan dengan hasil perhitungan serta dengan yang ada di pasaran?

\section{Batasan Masalah}

1. Untuk memperjelas ruang lingkup permasalahan yang dibahas, maka penulis perlu adanya batasan-batasn yang akan diuraikan, antara lain: Perencanaan perhitungan beban yang diterima konstruksi

2. Perhitungan perencanaan roda gigi azimuth, poros, pasak, bearing/bantalan dan pelumasan.

3. Pemilihan motor DC penggerak azimuth

4. Tidak membahas rangkaian elektrik kotak kontrol.

\section{KAJIAN PUSTAKA}

\section{RCWS (Remote Control Weapon System)}

RCWS (Remote control weapon system)

adalahdudukan senjata yang dilengkapi dengan sistem penggerak elektrik, dengan menggunakan sistem kontrol arduino bluetooth sasaran musuh jarak dekat maupun jauh. 
Sistem pengendali buethoot ini berfungsi untuk mengatur pergerakan sudut azimuth dan sudut elevasi robot tempur kota.Sedangkan pada robot tempur kota ini menggunakan senjata SS2 V4 untuk melumpuhkan musuh dalam pertempuran perkotaan.

Sistem RCWS (Remote Control Weapon System) yang dirancang pada robot tempur kota ini memiliki desain atau fitur yang ergonomis dan kokoh serta memiliki kemampuan dalam penembakan yang jauh lebih akurat dan tepat dengan pembidikan dan hasil penembakan yang lebih presisi serta softwareyang lebih baik, dengan menggunakan sistem Arduino.

\section{Kriteria Secara Umum}

1. RCWS (Remote Control Weapon System) dapat dioperasionalkan menggunakan sistem kendali denganinstrumen arduino / bluetooth.

2. Putaran azimuth dan elevasi serta penembakan dilakukan oleh penembak secara elektrik dengan instumen arduino / bluetooth.

3. Alat kendali robot tempur kota maupun RCWS dari robot dapat dikendalikan dengan jarak jauh.

4. Memiliki ketelitian dan ketepatan tembak dengan gerakan yang lebih smooth.

5. Memiliki desain atau fitur yang lebih ergonomis dan labih kokoh.

\section{Komponen Pendukung}

1. Roda Gigi Lurus (Spurs Gear)adalah suatu bentuk roda gigi yang dipakai untuk memindahkan gerakkan antara poros. Poros sejajar, biasanya yang berbentuk silindris dan gigi-giginya adalah harus lurus dan sejajar dengan sumbu putaran.
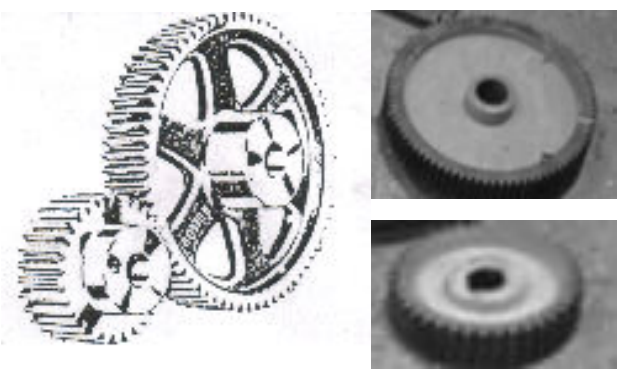

Gambar 1. Roda gigi lurus (Sumber : Zainun achmad, Elemen Mesin -1. Refika Aditama, 1999)

2. Poros merupakan salah satu bagian yang terpenting dari setiap mesin, hampir setiap mesin meneruskan tenaga bersama-sama dengan putaran lewat poros. Jadi poros digunakan untuk meneruskan daya yang akan di transmisikan melalui roda gigi,kopling serta pulley. Beban yang terjadi pada poros dapat berupa beban lentur dan puntir.Poros yang di pakai untuk Azimuth RCWS (Remote Control Weapon System) ini dibuat dari baja batang yang ditarik dingin dan difinis,meskipun demikian bahan ini kelurusannya agak kurang tetap dan dapat mengalami deformasi,karena tegangan yang kurang seimbang misalnya diberi alur pasak,karena ada tegangan sisa di dalam terasnya. Tapi penarikan dingin ini membuat permukaan poros menjadi keras dan kekuatannya bertambah besar. Batang baja yang saya gunakan adalah S35C.

3. Pasak adalah bagian dari elemen mesin yang digunakan untuk menetapkan atau menyambung dan untuk menjaga hubungan putaran relatif antara poros dari mesin 
dengan elemen seperti kopling, roda gigi, pully, sprocket, roda gila dan sebagainya, yang disambungkan dengan poros elemen tersebut. Bahan pasak dipilih bahan yang mempunyai kekuatan tarik tidak melebihi dari bahan poros, sehingga bila terjadi kerusakan diharapkan poros tidak lebih dahulu rusak, tetapi cukup pasaknya terlebih dahulu. Sebab pasak lebih murah dan pembuatannya lebih mudah dibandingkan poros.
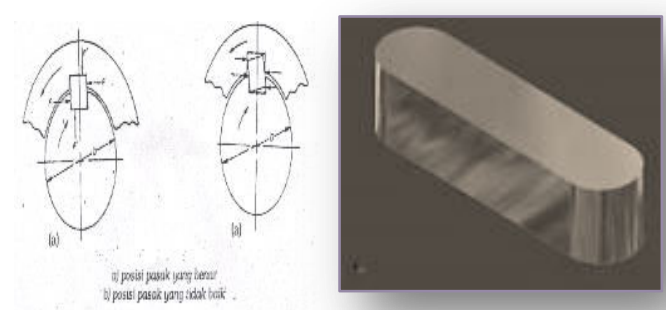

Gambar 2 : Pasak Benam

(Sumber : Zainun achmad, Elemen Mesin -1. Refika Aditama, 1999, hal128. )

Pasak benam banyak diterapkan, baik pada konstruksi dimana roda harus dapat digeserkan pada poros maupun pada konstruksi dimana roda harus disambung tak bergerak dengan poros.Pasak benam rata hanya mendukung pada tepi sampingnya , jadi lebar pasak dan alur hanya disesuaikan dengan teliti, sebab kalau tidak, terutama pada arah gaya bertukar, terjadi tumbukkan dan pasak terancam menjadi lepas.Pemasangan pasak yang tepat toleransinya, akan dapat membuat distribusi tegangan yang merata di seluruh panjangnya pasak.Bila toleransinya tidak diperhatikan, maka pemasangan pasak menunjukkan posisi pasak yang tidak benar, sehingga menyebabkan distribusi tegangan yang tidak merata sepanjang pasak.

4. Bantalan mempunyai defenisi sebagai suatu elemen yang menumpu poros berbeban sehingga gerak bolak-baliknya berlangsung secara halus, aman dan berlangsung dalam jangka aktu yang lama. Bantalan harus cukup kuat untuk menopang elemen lainya terutama poros sehingga dapat bekerja dengan baik.Bantalan yang rencanakan adalah bantalan gelinding, karena beban dudukan/kubah ini kecil dan gesekannya juga rendah, putaran pada bantalan ini dibatasi oleh gaya sentrifugal yang timbul pada elemen mesin. Bahan yang digunakan adalah baja krom karbon tinggi, karena dapat memberikan efek stabil pada perlakuan panas dan dapat memberikan umur panjang dengan keausannya sangat kecil. Dengan pemakaian bantalan diharapkan kerusakan tidak terjadi pada poros utama, karena harga dari poros utama lebih mahal dari pada bantalan. Untuk lebih jelasnya dapat kita lihat bentuk bantalan gelinding pada gambar berikut ini:

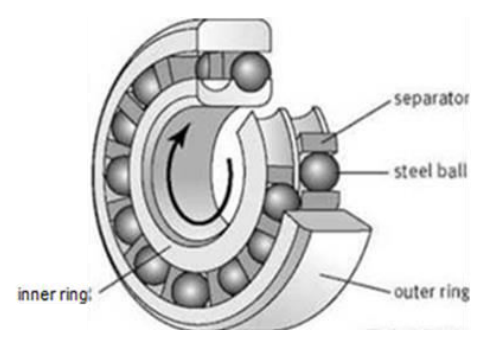

Gambar 3. Bantalan gelinding (Sumber : Sularso, 1997, hal 129)

5. Pelumasan adalah suatu perawatan mesin dengan memberikan cairan tertentu guna 
mendukung kerja dari suatu mesin. Adapun tujuan pelumasan adalah:

a. Mengurangi panas dan membawa panas yang terjadi akibat gesekan

b. Mengurangi gesekan dan keausan antara elemen gelinding dan sangkar.

c. Mencegah korosi

d. Mencegah masuknya debu kedalam elemen yang saling bergesekan.

Dalam hal ini saya merencanakan memakai pelumasan gemuk untuk baja bantalan kran karbon tinggi yang merupakan bahan bantalan yang saya gunakan. Pelumasan gemuk lebih sederhana dan semua gemuk yang bermutu baik dapat memberikan umur panjang cara pengemukan adalah dengan mengisi bagian dalam bantalan dengan gemuk sebanyak mungkin (diantara kedua cincin dan bola).Cara melakukan pelumasan :

1) Pelumasan gemuk yang bermutu baik dapat memberikan umur yang panjang pada elemen mesin.

2) Pelumasan minyak merupakan cara lebih berguna untuk kecepatan tinggi atau temperatur tinggi,yang sering digunakan pelumasan celup.

6. Motor DC adalah mesin yang mengubah tenaga listrik menjadi tenaga mekanik. Kerja motor didasarkan pada prinsip bahwa bilamana konduktor berarus ditempatkan pada medan magnet maka konduktor tersebut mengalami gaya mekanik.

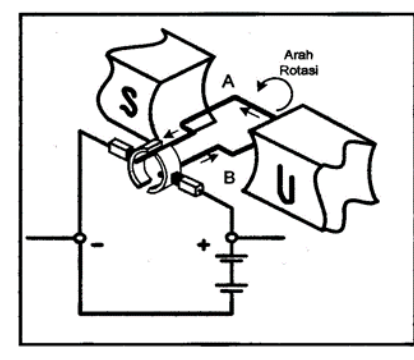

Gambar 4. Konstruksi dasar Motor DC (Sumber : Sularso, 1997)

Konstruksi dari motor DC terdiri dari stator (bagian yang tidak bergerak) dan rotor (bagian yang berputar). Stator motor bisa berupa magnet tetap ataupun kumparan yang mempunyai belitan medan, rotor atau jangkar merupakan bagian yang bergerak yang terbuat dari besi. Kumparan jangkar diletakkan pada slot disebelah luar permukaan jangkar. Pada jangkar terdapat komutator yang berbentuk silinder dan masing-masing diisolasi.

\section{Dasar Perencanaan}

1. Perbandingan reduksi (i)

$i=\frac{Z_{2}}{Z_{1}}$

Dimana :

$\mathrm{Z}$ = jumlah roda gigi

2. Diameter roda gigi (D)

$D=m \times Z$

Dimana :

$\mathrm{m}=$ Modul

3. Jarak sumbu poros (a)

$a=\frac{\left(D_{1}+D_{2}\right)}{2}$

4. Tegangan geser yang terjadi $\left(\tau_{\mathrm{s}}\right)$

$\tau=\frac{5,1 \times T}{d_{s}^{3}}$

Dimana : 


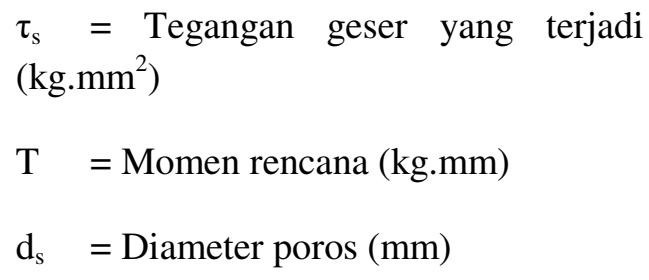

5. Defleksi puntiran $\theta\left({ }^{0}\right)$

$\theta=584 \frac{T \times l}{G \cdot d_{s}^{4}}$

Dimana :

$\mathrm{T}=$ Torsi $(\mathrm{kg} \cdot \mathrm{mm}$

$\mathrm{L}=$ Panjang poros yang di rencanakan $(\mathrm{mm})$

$\mathrm{G}=$ Modulus baja $\left(\mathrm{kg} / \mathrm{mm}^{2}\right)$

6. Putaran Kritis poros Nc (rpm)

$N_{e}=52700 \frac{d_{2}^{2}}{l_{1} l_{2}} \sqrt{\frac{l}{w}}$

Dimana :

$\mathrm{N}_{\mathrm{e}}=$ Putaran Kritis poros (rpm)

$\mathrm{W}=$ Berat beban $(\mathrm{kg})$

1 = Jarak antara bantalan ( $\mathrm{mm})$

$\mathrm{d}_{\mathrm{s}}=$ Diameter poros $(\mathrm{mm})$

$1_{1}$ dan $l_{2}=$ Jarak dari bantalan yang bersangkutan ke titik pembebanan (mm)

7. Diameter luar lingkaran kepala

$d_{k 1}=\left(Z_{1}+2\right) m$.

8. Tinggi gigi $\mathrm{H}(\mathrm{mm})$

$\mathrm{H}=2 . m+c K$

9. Kecepatan keliling (v)

$\vartheta=\frac{\pi \times d_{b} \times n}{60 \times 1000}$

10. Gaya Tangensial

$F_{t}=\frac{102 \cdot P_{d}}{\vartheta}$

11. Faktor Dinamis

$f_{\vartheta}=\frac{3}{3+\vartheta}$

12. Umur bantalan/Faktor kecepatan

$F_{n}=\left[\frac{33,3}{n_{1}}\right]^{1 / 3}$
13. Diameter bola gelinding

$\mathrm{Dw}=\mathrm{Q}_{1}(\mathrm{D}-\mathrm{d})$

Dimana :

$\mathrm{Q}=$ Faktor untuk bantalan bola satu baris

$\mathrm{D}=$ Diameter luar bantalan

$\mathrm{d}=$ Diameter dalam bantalan

14. Jumlah bola gelinding dalam satu baris

$Z=q_{1}(\mathrm{D}+\mathrm{d}) / \mathrm{D}_{\mathrm{w}}$

Dimana :

$\mathrm{Z}$ = Jumlah bola gelinding dalam satu baris

$\mathrm{q}_{2}=$ Faktor untuk bantalan bola satu baris (Tabel 14/3)

D = Diameter bantalan luar

\section{METODOLOGI PENELITIAN}

Langkah-langkah yang digunakan dalam perencanaan ini adalah :

1. Melakukan pengambilan data perhitungan dari lengan dan dudukan RCWS dari penelitian sebelumnya.

2. Melakukan perhitungan sesuai dengan rumus serta menentukan sketsa alat.

3. Membuat alat sesuai dengan hasil perhitungan.

4. Perakitan alat dan mengoperasionalkan untuk mengetahui kendala yang kemungkinan terjadi.

5. Menganalisa selanjutnya dilakukan penyempurnaan.

\section{Variabel yang Direncanakan}


1. Variabel bebas adalah variabel yang besarnya ditentukan oleh penulis, diantaranya sebagai berikut :

a. Modul dan jumlah gigi.

b. Kecepatan putar azimuth

c. Bahan poros dan Bantalan.

2. Variabel terikat adalah variabel yang besarnya tidak dapat ditentukan oleh penulis tetapi besarnya tergantung pada variabel bebasnya. Dalam perencanaan ini variabel terikatnya adalah :

a. Dimensi atau ukuran poros dan pasak.

b. Putaran Motor

\section{Cara Kerja Alat}

Rangkaian sistem azimuth ini dikendalikan menggunakan sistem arduino dengan koneksi bluetooth pada android. Pada saat system mulai dijalankan Arduino akan mengirimkan sinyal pada motor DC dan gerakan motor DC akan bergerak sesuai perintah yang didapatkan dari Arduino.

Putaran motor DC akan memutar gear box pada motor DC, penggunaan gear boxbertujuan untuk mendapatkan putaran yang lebih halus. Putaran dari motor DC akan diturunkan lewat perbandingan gigi-gigi yang merupakan rangkaian kerja untuk mendapatkan putaran yang diinginkan.

Rangkaian gear boxuntuk motor penggerak azimut terdiri dari roda gigi miring yang bergerak satu poros dengan roda gigi lurus. Putaran dari motor DC diteruskan roda gigi miring, dimana bentuk poros motor adalah poros cacing. Putaran roda gigi 1 diperlambat oleh roda gigi 2 yang diameternya lebih kecil, yang selanjutnya akan diteruskan ke roda gigi poros azimuth, selanjutnya roda gigi poros azimuth akan meneruskan putaran ke poros azimuth dan poros azimut akan memutar lengan RCWS yang bersambungan langsung dengan rangkaian sistem azimuth. Untuk lebih jelasnya dapat dilihat pada gambar:

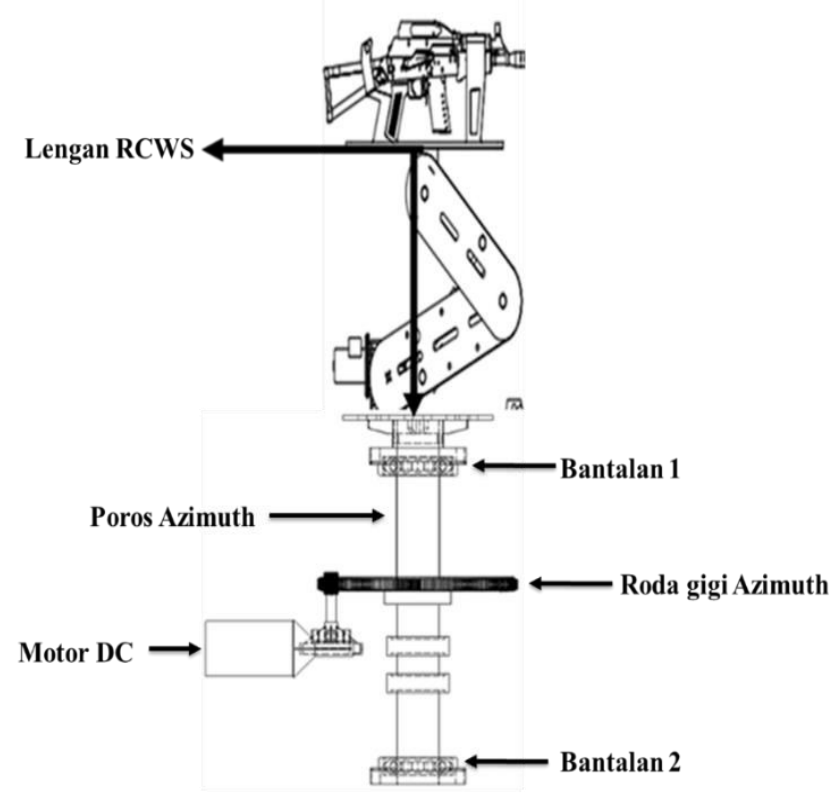

Gambar 5. Rangkaian sistem azimuth.

\section{Diagram Alir}




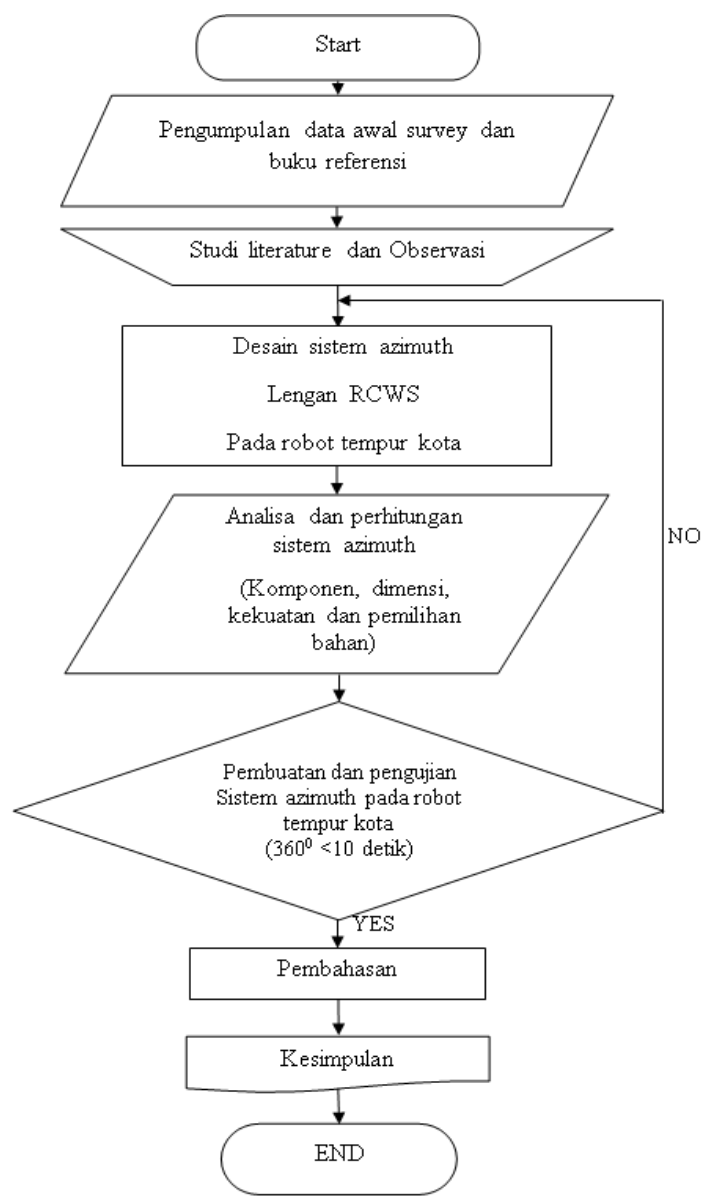

\begin{tabular}{|l|c|c|c|c|}
\hline \multicolumn{1}{|c|}{ Roda gigi } & Simbol & Satuan & I & II \\
\hline Perbandingan reduksi & $\mathrm{i}$ & - & 11,2 & 11,2 \\
\hline Diameter roda gigi & $\mathrm{D}$ & $\mathrm{mm}$ & 27 & 303 \\
\hline Jarak sumbu poros & $\mathrm{a}$ & $\mathrm{mm}$ & 89,852 & 89,852 \\
\hline Jumlah putaran roda gigi & $\mathrm{n}_{2}$ & $\mathrm{rpm}$ & 8 & 8 \\
\hline Diametral pitch & $\mathrm{dp}$ & $\mathrm{mm}$ & 0,3 & 0,336 \\
\hline Tebal gigi & $\mathrm{t}$ & $\mathrm{mm}$ & 4,71 & 4,71 \\
\hline Diameter ling. Kepala & $\mathrm{dk}$ & $\mathrm{mm}$ & 33 & 309 \\
\hline Tinggi kepala gigi & $\mathrm{hk}$ & $\mathrm{mm}$ & 3 & 3 \\
\hline Kelonggaran puncak & $\mathrm{Ck}$ & $\mathrm{mm}$ & 0,75 & 0,75 \\
\hline Tinggi kaki gigi & $\mathrm{hf}$ & $\mathrm{mm}$ & 3,75 & 3,75 \\
\hline Tinggi gigi & $\mathrm{H}$ & $\mathrm{mm}$ & 3,675 & 3,675 \\
\hline Diameter lingkaran dasar & $\mathrm{dg}$ & $\mathrm{mm}$ & 19,5 & 295,5 \\
\hline Kecepatan keliling & $\mathrm{v}$ & $\mathrm{m} / \mathrm{s}$ & 0,033912 & 0,380568 \\
\hline Gaya tangensial & $\mathrm{Ft}$ & $\mathrm{Kg}$ & 61,35 & 5,467 \\
\hline Lebar sisi gigi & $\mathrm{b}$ & $\mathrm{mm}$ & 30 & 30 \\
\hline Tegangan lentur terjadi & $\sigma_{t}$ & $\mathrm{Kg} / \mathrm{mm}^{2}$ & 18,667 & 1,663 \\
\hline Tegangan geser terjadi & $\tau_{a}$ & $\mathrm{Kg} / \mathrm{mm}^{2}$ & 0,302 & 0,027 \\
\hline Tegangan geser izin & $\tau_{i}$ & $\mathrm{Kg} / \mathrm{mm}^{2}$ & 20,8 & 20,8 \\
\hline Berat roda gigi & $\mathrm{w}$ & $\mathrm{Kg}$ & 0,134 & 4,92 \\
\hline
\end{tabular}

Tabel 3. Rekapitulasi hasil perhitungan poros

\begin{tabular}{l|l|c|c|c|}
\hline \multicolumn{1}{|c|}{ Poros } & Simbol & Satuan & Hasil \\
\hline Daya yang diharuskan & $\mathrm{Pd}$ & $\mathrm{kW}$ & 0,0165 \\
\hline Momen torsi & $\mathrm{Tr}$ & $\mathrm{Kg} \cdot \mathrm{mm}$ & 2009,29 \\
\hline Tegangan geser izin & $\tau_{a}$ & $\mathrm{Kg} / \mathrm{mm}^{2}$ & 4,33 \\
\hline Diameter poros & $\mathrm{ds}$ & $\mathrm{mm}$ & 25,37 \\
\hline Tegangan geser yang terjadi & $\tau_{s}$ & $\mathrm{Kg} / \mathrm{mm}^{2}$ & 0,379 \\
\hline Berat poros & $\mathrm{w}$ & $\mathrm{Kg}$ & 1,928 \\
\hline Defleksi puntiran & $\theta$ & ${ }^{\circ}$ & 0,061 \\
\hline Lendutan poros & $\mathrm{y}$ & $\mathrm{mm}$ & 0,00174 \\
\hline Momen inersia & $\mathrm{I}$ & $\mathrm{m}{ }^{4}$ & 39740,625 \\
\hline & Buckling & $\mathrm{K}$ & $\mathrm{N}$ & $2,23 \times 10^{17}$ \\
\hline Gaya tekan izin & $\mathrm{F}$ & $\mathrm{N}$ & $5,39 \times 10^{16}$ \\
\hline & Putaran kritis poros & $\mathrm{Ne}$ & $\mathrm{Rpm}$ & 21696,083 \\
\hline
\end{tabular}

Tabel 4. Rekapitulasi hasil perhitungan

HASIL DAN PEMBAHASAN

Hasil Perhitungan

Tabel 1. Rekapitulasi hasil perhitungan pada beban maksimal

\begin{tabular}{|c|c|c|c|} 
NO & Bagian & Sudut $\left({ }^{0}\right)$ & Beban (N) \\
\hline 1 & Lengan 1 & $90^{\circ}$ & $107,05 \mathrm{~N}$ \\
\hline 2 & Lengan 2 & $90^{\circ}$ & \\
\hline 3 & \multicolumn{2}{|c|}{ Beban Maksimal } & $162,62 \mathrm{~N}$ \\
\hline
\end{tabular}

pasak

Tabel 2. Rekapitulasi hasil perhitungan roda gigi lurus

\begin{tabular}{l|l|c|c|c|}
\hline $\mathbf{1}$ & \multicolumn{1}{|c|}{ Pasak } & Simbol & Satuan & Hasil \\
\hline $\mathbf{1}$ & Kekuatan tarik bahan pasak & $\sigma_{\mathrm{b}}$ & $\mathrm{Kg} / \mathrm{mm}$ & 52 \\
\hline $\mathbf{2}$ & Tegangan geser izin & $\tau_{a}$ & $\mathrm{Kg} / \mathrm{mm}^{2}$ & 4,3 \\
\hline $\mathbf{3}$ & $\begin{array}{l}\text { Gaya tangensial permukaan } \\
\text { pasak }\end{array}$ & $\mathrm{F}$ & $\mathrm{Kg}$ & 133,95 \\
\hline $\mathbf{4}$ & Tegangan geser yang terjadi & $\tau_{s}$ & $\mathrm{Kg} / \mathrm{mm}^{2}$ & 0,478 \\
\hline $\mathbf{5}$ & Tekanan permukaan izin & $\mathrm{P}$ & $\mathrm{Kg} / \mathrm{mm}^{2}$ & 0,956 \\
\hline $\mathbf{6}$ & Ukuran pasak & - & & $10 \times 8$ \\
\hline $\mathbf{7}$ & Panjang pasak & - & $\mathrm{mm}$ & 28 \\
\hline
\end{tabular}

Tabel 5. Rekapitulasi hasil perhitungan bantalan

\begin{tabular}{|c|l|c|c|c|}
\hline No & \multicolumn{1}{|c|}{ Bantalan } & Simbol & Satuan & Hasil \\
\hline $\mathbf{1}$ & Beban aksial & $\mathrm{Fa}$ & $\mathrm{Kg}$ & 81,4 \\
\hline $\mathbf{2}$ & Beban pada bantalan & $\mathrm{P}$ & $\mathrm{Kg}$ & 9,29 \\
\hline $\mathbf{3}$ & Faktor kecepatan & $\mathrm{Fn}$ & $\mathrm{Rpm}$ & 1,608 \\
\hline $\mathbf{4}$ & Faktor umur & $\mathrm{Fh}$ & $\mathrm{Jam}$ & 178,29 \\
\hline $\mathbf{5}$ & Umur nominal 8 jam/hari & $\mathrm{Lh}$ & Tahun & 30,53 tahun \\
\hline $\mathbf{6}$ & Diameter bola gelinding & $\mathrm{Dw}$ & $\mathrm{mm}$ & 6,25 \\
\hline $\mathbf{7}$ & Jumlah bola gelinding & $\mathrm{Z}$ & Buah & 4 \\
\hline & Bantalan kaki poros & Simbol & Satuan & Hasil \\
\hline $\mathbf{1}$ & Tekanan merata & $\mathrm{P}$ & $\mathrm{Kg} / \mathrm{cm}^{2}$ & 0,649 \\
\hline $\mathbf{2}$ & Total gesekan torsi & $\mathrm{T}$ & $\mathrm{Kg} \cdot \mathrm{m}$ & 0,0314 \\
\hline $\mathbf{3}$ & Daya yang hilang & $\mathrm{P}_{1}$ & $\mathrm{Hp}$ & 0,951 \\
\hline
\end{tabular}

Hasil perhitungan pelumasan pada bantalan menggunakan gemuk, umur gemuk 
apabila bantalan digunakan selama 8 jam/hari adalah selama 28,93 tahun.

Tabel 6. Rekapitulasi hasil perhitungan dan nilai beban sistem RCWS

\begin{tabular}{|c|c|c|c|}
\hline NO & \multicolumn{3}{|c|}{ Perhitungan Beban } \\
\hline 1 & Beban Total & $17,514 \mathrm{~kg}$ & $172 \mathrm{~N}$ \\
\hline 2 & Lengan 1 & $60^{\circ}$ & $58,03 \mathrm{~N}$ \\
\hline 3 & Lengan 2 & $20^{\circ}$ & $161,28 \mathrm{~N}$ \\
\hline
\end{tabular}

Dalam perhitungan beban pada sistem azimuth RCWS ini diperoleh hasil beban total yang diterima adalah sebesar 16,594 kg, dengan sudut pada beban maksimal lengan 1 yaitu $90^{\circ}$ sebesar $107,05 \mathrm{~N}$ dan lengan 2 pada sudut $90^{\circ}$ sebesar $162,62 \mathrm{~N}$.

Tabel 7. Rekapitulasi hasil perhitungan dan nilai aktual roda gigi lurus

\begin{tabular}{|c|c|c|c|c|}
\hline RODA GIGI IURUS & SATUAN & AKTUAI. & $\begin{array}{l}\text { PERHITU- } \\
\text { NGAN }\end{array}$ & $\begin{array}{r}\begin{array}{r}\text { Perbedaa } \\
\text { selisih\% } \%\end{array} \\
\end{array}$ \\
\hline Roda gigi kecil & gigi & 9 & 9 & $0 \%$ \\
\hline Diameter roda gigi & $\mathrm{mm}$ & 27 & 27 & $0 \%$ \\
\hline Tinggi gigi & $\mathrm{mm}$ & 10 & 6,75 & $33 \%$ \\
\hline Lebar sisi gigi & $\mathrm{mm}$ & 30 & 30 & $0 \%$ \\
\hline Roda gigi besar & gigi & 101 & 101 & $0 \%$ \\
\hline Diameter poros dinamis & $\mathrm{mm}$ & 30 & 30 & $0 \%$ \\
\hline Diamcter roda gigi & $\mathrm{mm}$ & 303 & 303 & $0 \%$ \\
\hline Lcbar sisi gigi & $\mathrm{mm}$ & 30 & 30 & $0 \%$ \\
\hline T'inggi gigi & $\mathrm{mm}$ & 10 & 6,75 & $33 \%$ \\
\hline
\end{tabular}

perhitungan dan aktual pada roda gigi lurus yang digunakan ada beberapa perbedaan diantaranya tinggi gigi pada roda gigi lurus 10 mm untuk aktual dan perencanaan hasil perhitungan $6,75 \mathrm{~mm}$ selisih $33 \%$ dari nilai aktual yang digunakan.

Dengan adanya perbedaan pada tinggi gigi lurus hasil perhitungan dan nilai aktual yang digunakan disebabkan adanya perbedaan nilai faktor koreksi, faktor keamanan dan bahan yang digunakan oleh perencanaan. Pengambilan keputusan ini didasarkan pada referensi-referensi yang ada, sehingga memungkinkan adanya perbedaan nilai-nilai yang digunakan antara aktual dengan hasil perhitungan.

Tabel 7. Rekapitulasi hasil perhitungan dan nilai aktual Poros dinamis dan pasak.

\begin{tabular}{|l|c|c|c|c}
\hline \multicolumn{1}{|c|}{ POROS } & SATUAN & AKTUAL & $\begin{array}{c}\text { PERHITU- } \\
\text { NGAN }\end{array}$ & $\begin{array}{c}\text { Perbedaan } \\
\text { selisih\% }\end{array}$ \\
\hline Poros Dinamis & buah & 1 & - & - \\
\hline Panjang & $\mathrm{mm}$ & 350 & 350 & $0 \%$ \\
\hline Diameter & $\mathrm{mm}$ & 30 & 30 & $0 \%$ \\
\hline Pasak Dinamis & buah & 1 & - & - \\
\hline Panjang & $\mathrm{mm}$ & 30 & 28 & $6,6 \%$ \\
\hline Lebar & $\mathrm{mm}$ & 8 & 10 & $25 \%$ \\
\hline Tinggi & $\mathrm{mm}$ & 7 & 8 & $14,2 \%$ \\
\hline
\end{tabular}

\section{Poros}

Dalam merencanakan poros hal-hal yang harus diperhatikan antara lain momen puntir yang terjadi, putaran, beban yang ditanggung, momen lentur, dan juga beban kejut akan terjadi pada poros. Hal-hal tersebut yang menyebabkan pemilihan bahan poros agak sedikit rumit. Pemilihan bahan yang akan digunakan didasarkan pada kekuatan tarik $\left(\sigma_{\mathrm{B}}\right)$ dari bahan tesebut, karena nilai tersebutlah yang akan digunakan untuk menghitung besar diameter poros.

Perencanaan perhitungan dan aktual pada poros dinamis yang digunakan saat ini sesuai yang diharapkan dengan diameter 30 $\mathrm{mm}$ dan panjang $350 \mathrm{~mm}$. Hal ini karena memperhatikan defleksi puntiran yang diijinkan dan juga diameter bantalan yang akan dipasang pada poros tersebut. Penentuan panjang poros tidak hanya didasarkan pada hasil perhitungan saja, tetapi juga harus disesuaikan dengan kondisi dan posisi poros yang digunakan.

\section{Pasak}

DOI: doi.org/10.26905/jtmt.v16i1.4498 
Untuk menentukan pasak yang akan digunakan, baik dimensi maupun jenis pasak, hal-hal yang harus diperhatikan antara lain adalah tegangan permukaan poros, gaya tangensial poros, tegangan geser yang terjadi pada pasak, dan tegangan geser ijin pasak.

Tegangan geser ijin pasak sangat dipengaruhi oleh jenis bahan yang digunakan. Pada pasak poros dinamis terjadi adanya perbedaan pada ukuran nominal pasak perhitungan perencanaan dan aktual. Pada pasak poros dinamis yang direncanakan dengan ukuran nominal $10 \times 8 \mathrm{~mm}$ (bxh) dan yang digunakan $8 \times 7 \mathrm{~mm}$ (bxh) selisih antara $25 \%$ dan $14,2 \%$ pada Ukuran nominal pasak (bxh) ini disebabkan karena sulitnya ukuran nominal pasak didapat dipasaran sehingga digunakanlah ukuran nominal pasak yang ada tersebut. Ukuran dan bentuk standar pasak diberikan dalam tabel ukuran tentang pasak. Bahan pasak mempunyai kekuatan tarik lebih kuat dari poros agar pasak lebih dulu rusak, karena pasak harganya murah dan mudah diganti.

Tabel 8. Rekapitulasi data hasil perhitungan dan nilai aktual Bantalan gelinding

\begin{tabular}{|l|c|c|c|c|}
\hline \multicolumn{1}{|c|}{ BANTALAN } & SATUAN & AKTUAL & $\begin{array}{c}\text { PERHITU- } \\
\text { NGAN }\end{array}$ & $\begin{array}{c}\text { Perbedaan } \\
\text { selisih\% }\end{array}$ \\
\hline Bantalan dinamis & Buah & 1 & - & - \\
\hline Jenis bantalan & - & - & terbuka & - \\
\hline Nomor bantalan & - & - & 6006 & - \\
\hline Diameter dalam & $\mathrm{mm}$ & 30 & 30 & $0 \%$ \\
\hline Diameter luar & $\mathrm{mm}$ & 55 & 55 & $0 \%$ \\
\hline Lebar bantalan & $\mathrm{mm}$ & 16 & 15 & $6 \%$ \\
\hline Jari-jari filet bantalan & $\mathrm{mm}$ & 1,5 & 1,5 & $0 \%$ \\
\hline Diameter bola gelinding & $\mathrm{mm}$ & 7 & 6,25 & $11 \%$ \\
\hline Jumlah bola gelinding & buah & 6 & 4 & $33,3 \%$ \\
\hline
\end{tabular}

Tabel 9. Rekapitulasi data hasil perhitungan dan nilai aktual Bantalan gelinding kaki poros

\begin{tabular}{|l|c|c|c|c|}
\hline \multicolumn{1}{|c|}{ BANTALAN } & SATUAN & AKTUAL & $\begin{array}{c}\text { PERIITU- } \\
\text { NGAN }\end{array}$ & $\begin{array}{c}\text { Perbedaan } \\
\text { selisih\% }\end{array}$ \\
\hline Bantalan kaki poros & Buah & 1 & - & - \\
\hline Jenis bantalan & - & - & terbuka & - \\
\hline Nomor bantalan & - & - & 6008 & - \\
\hline Diameter dalam & $\mathrm{mm}$ & 30 & 30 & $0 \%$ \\
\hline Diameter luar & $\mathrm{mm}$ & 55 & 55 & $0 \%$ \\
\hline Lebar bantalan & $\mathrm{mm}$ & 16 & 15 & $6 \%$ \\
\hline Jari-jari filet bantalan & $\mathrm{mm}$ & 1,5 & 1,5 & $0 \%$ \\
\hline Diameter bola gelinding & $\mathrm{mm}$ & 7 & 6,25 & $11 \%$ \\
\hline Jumlah bola gelinding & buah & 6 & 4 & $33,3 \%$ \\
\hline
\end{tabular}

\section{Bantalan}

Dalam merencanakan bantalan hasil perhitungan dan aktual yang digunakan pada bantalan dinamis dan bantalan kaki poros ada perbedaan dari hasil perhitungan lebar bantalan $15 \mathrm{~mm}$ dan aktual yang digunakan $16 \mathrm{~mm}$ dengan selisih $6 \%$. Selanjutnya perbedaan hasil perhitungan pada diameter bola gelinding dalam perhitungan $6,25 \mathrm{~mm}$ dan dalam aktual $7 \mathrm{~mm}$ dengan selisih $11 \%$ serta pada jumlah bola gelinding 4 buah dan aktual yang digunakan 6 buah jadi selisihnya 33,3\%. Dengan adanya perbedaan hasil perhitungan dan aktual yang disebabkan oleh adanya nilai faktor koreksi. Adanya bantalan aktual yang digunakan karena sesuai yang diharapkan dan beban yang diterima oleh bantalan gelinding 
mampu untuk putaran sederhana disamping itu juga ketersediaan bantalan yang ada dipasaran dengan penyesuaian perhitungan. Hal ini disebabkan karena pembuatan bantalan selain rumit juga membutuhkan biaya yang besar.

Adanya perbedaan dari hasil perhitungan dan nilai aktual pada elemen mesin yang digunakan pada rangkaian azmuth karena disebabkan adanya nilai faktor keamanan, tegangan geser, faktor lenturan dan faktor koreksi tumbukan.

\section{Pelumasan}

Jenis pelumasan dan metode pelumasan sangat menentukan umur dan performa dari suatu perangkat mesin. Dalam memilih jenis pelumas dan metode pelumasan harus diperhatikan posisi dan kondisi kerja dari komponen yang dilumasi. Dalam perencanaan perhitungan,dipilih pelumasan menggunakan gemuk karena penyekatnya lebih sederhana dan dapat memberikan umur panjang. memudahkan pelumasan dengan gemuk, mengingat juga biaya pelumasan gemuk lebih mudah dan murah.

\section{Motor DC}

Pemilihan motor menggunakan motor DC sesuai dengan yang tersedia di pasaran tipe AX - 12 dengan kecepatan putaran (n) 2400 rpm untuk menggerakan gearbox pada motor dan diteruskan menuju transmisi roda gigi pinion dan roda gigi besar. Tegangan $(\mathrm{V})=24$ volt, arus $(\mathrm{I})=10$ Ampere dengan torsi sebesar 24,5166 Nm. Digunakan untuk memutar azimuth dengan kecepatan (v) adalah sebesar
0,117 m/s, dengan torsi (T) sebesar 24,393 Nm dan daya $(\mathrm{P})$ sebesar $0,0204 \mathrm{~kW}$.

\section{SIMPULAN}

Dari hasil perhitungan dapat disimpulkan sebagai berikut:

1. Telah dapat direncanakan dan dibuat Rangkaian sistem azimuth pada RCWS (Remote control weapon system) sesuai perhitungan dan dengan komponenkomponen yang ada di pasaran.

2. Adanya perbedaan dari hasil perhitungan dan nilai aktual pada elemen mesin yang digunakan pada rangkaian azmuth karena disebabkan adanya bahan,faktor koreksi,koefesien,efesien daya yang ditransmisikan dan konstanta material (E).

3. Ketersediaannya komponen-komponen RCWS seperti roda gigi lurus, bantalan, dan pasak yang digunakan disesuikan dengan yang ada di pasaran.

\section{DAFTAR PUSTAKA}

Arismunandar, 2017, Rancang BangunMekanik Azimuth RCWS pada Robot Tempur Kota, Tugas akhir D-3 Politeknik Kodiklat TNI AD Malang.

Deutsman,A.D,Walter J. Michel,Charles E.Wilson, Machine design Theory and practice, Coller Macmillan, Publishing Co. Inc.1975.

Dr. Ing M Hirt,1986, Elemen Mesin, Erlangga, Jakarta.

Niemann.G dan Winter.H, 1990, Elemen Mesin Desain dan Kalkulasi dari Sambungan, Bantalan, dan Poros,PT Gelora Aksara Paratama, Jilid 1, Penerbit Erlangga, Jakarta. 
Khurmi, R.S. Gupta, J.K.2005. A Textbook for the students of Machine Design (S.I. Units). Ram-Nagar, New Delhi : Eurasia Publishing House (PVT.) LTD.

Kiyokatsu Suga dan Sularso, 1994, Dasar Perencanaan dan Pemilihan Elemen Mesin, PT. Pradnya Paramita, Jakarta.

Latifnurkhasan, 2017, Rancang BangunLengan RCWS pada Robot Tempur Kota, Tugas akhir D-3 Politeknik Kodiklat TNI AD Malang.

Popov, EP dan Tanisan Astamar Zainul, 1993, Mekanika Teknik, PT Gelora Aksara Paratama, Edisi Kedua, Penerbit Erlangga, , Jakarta

Sularso, Ir. Dasar Perencanaan dan Pemilihan Elemen Mesin. Jakarta: Pradya Paramita, 1985.

Sularso Ir., MSME, Dasar Perencanaan dan Pemilihan Elemen Mesin, PT. Pradnya Paramita, 1997.

Zainun, achmad, 1999, Elemen Mesin-1.

Refika Aditama, Jakarta. https://www.academia.edu/8684846/E

lemen_Mesin_1_Bantalan

http://id.wstbearinguae.com/pillow-blockbearing/pillow-block-bearingucf/pillow-block-bearing-ucf-205.html 